\title{
The effect of varying RDP: UDP ratios on intake and milk production efficiency in Saanen ewes fed a complete diet
}

\author{
J.D. Thornton and A.V. Ferreira \\ Dept of Animal Science, University of Stellenbosch, Stellenbosch, 7600
}

\section{Introduction}

At present the milk goat industry in South Africa is underdeveloped, yet has the potential to grow into a viable industry. Studies of the nitrogen requirements of dairy goats during lactation are scarce (Mishra, et al., 1996; Brun-Bellut \& Kelly, 1991) and the RDP: UDP requirements of dairy goats are not well documented. The present study aims to determine the effect of different RDP: UDP ratios on milk production, feed intake, body weight and milk composition.

\section{Material and Methods}

Twenty-four lactating Saanen ewes were divided according to milk production and lactation number, into three groups of eight individuals. Each group was allocated to one of the experimental protein diets: low degradability (LD), medium degradability (MD) and high degradability (HD), on an ad-lib feeding regime. The RDP: UDP ratios in the pelleted diets were approximately 55:45; 62:38 and 72:28. The LD and HD diets were isonitrogenous, with $16 \% \mathrm{CP}$ on a dry matter basis, whereas the MD diet contained $20 \%$ less $\mathrm{CP}(12.8 \%)$ and all the diets were iso-caloric. Local fish meal and cotton oilcake (45\%) was used as natural sources of UDP. The experiment was carried out over a 112 day lactation period divided into four 28-day stages, starting approximately 24 days post partum, to ensure that pre-peak, peak and post-peak production was recorded. The ewes were milked twice daily at 6:30 and 15:30 and milk production was recorded after each milking. The body weight, feed intake and milk samples for analysis were taken on a weekly basis.

\section{Results and Discussion}

From Table 1 it is clear that the RDP: UDP ratios have no significant influence on the milk production of the Saanen ewes, through any of the stages of the experiment. Due to the large coefficient of variation no significant differences were achieved in the milk production, yet it appears that the LD diet had a higher milk production. Feed intake showed significant differences $(\mathrm{P}<0.05)$ from the second to the fourth stage $(53-139$ days in lactation) of the experiment. The feed conversion efficiency of the HD diet was significantly $(\mathrm{P}<0.05)$ better than the LD diet in the second lactation stage of the experiment. Although not significant, this trend in FCE was maintained through out the experiment Milk fat $\%$ was significantly different over the third and fourth lactation stage of the experiment with the MD diet being different from the HD diet, and neither of the two diets being significantly different from LD diet. Milk lactose \% differed significantly between the LD diet and the MD diet, but neither was different from the HD diet over the second lactation stage (53-81 days in lactation).

\section{Conclusion}

Over the stages examined, the RDP: UDP ratios in the diet had no significant effect on the milk production. Feed intake was significantly influenced by the RDP: UDP ratio and the LD diet achieved a higher feed intake than the MD and HD diets. The HD diet has a better feed conversion efficiency largely due to a better utilisation of body reserves to complement available protein (Change in body Weight, Table 1). The milk composition was not significantly influenced, except for the MD diet that had the highest milk fat \% over the later part of the experiment 
Table 1. Influence of RDP:UDP ratio on feed intake, milk production and milk composition.

\begin{tabular}{|c|c|c|c|c|}
\hline \multirow{2}{*}{$\begin{array}{l}\text { Lactation } \\
\text { Stage } \\
\text { (days) }\end{array}$} & \multicolumn{2}{|c|}{ Experimental diets } & \multicolumn{2}{|r|}{ SEM } \\
\hline & $\mathrm{LD}^{1}$ & $\mathrm{MD}^{2}$ & $\mathrm{HD}^{3}$ & \\
\hline \multicolumn{5}{|l|}{ First Stage (24-52 days) } \\
\hline Feed Intake $(\mathrm{kg})$ & 1.5468 & 1.3105 & 1.4572 & 0.141727 \\
\hline $\begin{array}{l}\text { Change in Body } \\
\text { weight }(\mathrm{kg})\end{array}$ & $3.3125^{\mathrm{a}}$ & $-1.2875^{b}$ & $-2.5833^{b}$ & 1.368107 \\
\hline Milk Production (kg/day) & 2.6483 & 2.2158 & 2.8338 & 0.241007 \\
\hline FCE (kg milk/ kg feed) & 1.6744 & 1.7612 & 1.7878 & 0.116889 \\
\hline Milk Protein $(\%)$ & 2.8653 & 2.7675 & 2.8625 & 0.056973 \\
\hline Milk Fat $(\%)$ & 2.6221 & 2.8662 & 2.6216 & 0.197154 \\
\hline Milk Lactose $(\%)$ & 4.5986 & 4.6128 & 4.6720 & 0.092729 \\
\hline \multicolumn{5}{|c|}{ Second Stage (53 - 81 days) } \\
\hline Feed Intake $(\mathrm{kg})$ & $2.3175^{\mathrm{a}}$ & $1.6939^{b}$ & $1.6754^{b}$ & 0.157312 \\
\hline $\begin{array}{l}\text { Change in Body } \\
\text { weight }(\mathrm{kg})\end{array}$ & -0.8750 & -3.2857 & -3.1667 & 1.479802 \\
\hline Milk Production (kg/day) & 3.0017 & 2.5571 & 3.0128 & 0.308466 \\
\hline FCE (kg milk/ kg feed) & $1.3332^{\mathrm{b}}$ & $1.6133^{\mathrm{ab}}$ & $1.7951^{\mathrm{a}}$ & 0.111366 \\
\hline Milk Protein $(\%)$ & 2.7729 & 2.8201 & 2.8692 & 0.070979 \\
\hline Milk Fat $(\%)$ & 2.3776 & 2.5499 & 2.4983 & 0.179210 \\
\hline \multicolumn{5}{|c|}{ Third Stage (82 - 110 days $)$} \\
\hline Feed Intake $(\mathrm{kg})$ & $2.3245^{\mathrm{a}}$ & $1.8122^{b}$ & $1.9031^{\mathrm{b}}$ & 0.123197 \\
\hline $\begin{array}{l}\text { Change in Body } \\
\text { weight }(\mathrm{kg})\end{array}$ & 1.0000 & 0.2143 & 1.1767 & 0.845129 \\
\hline Milk Production (kg/day) & 3.2112 & 2.7060 & 3.1431 & 0.312803 \\
\hline FCE (kg milk/ kg feed) & 1.3740 & 1.4895 & 1.6468 & 0.099323 \\
\hline Milk Protein $(\%)$ & 2.4978 & 2.5557 & 2.6096 & 0.049317 \\
\hline Milk Fat (\%) & $2.2622^{\mathrm{ab}}$ & $2.6204^{\mathrm{a}}$ & $2.1083^{b}$ & 0.143377 \\
\hline Milk Lactose (\%) & 4.4433 & 4.6195 & 4.5780 & 0.061460 \\
\hline \multicolumn{5}{|c|}{ Fourth Stage (111 - 139 days $)$} \\
\hline Feed Intake $(\mathrm{kg})$ & $2.2974^{\mathrm{a}}$ & $1.5949^{b}$ & $1.9427^{\mathrm{c}}$ & 0.092782 \\
\hline $\begin{array}{l}\text { Change in Body } \\
\text { weight }(\mathrm{kg})\end{array}$ & 1.8750 & 1.0714 & 1.9000 & 0.944888 \\
\hline Milk Production (kg/day) & 3.2175 & 2.4464 & 2.9092 & 0.289902 \\
\hline FCE (kg milk/ kg feed) & 1.4081 & 1.5354 & 1.5714 & 0.102659 \\
\hline Milk Protein $(\%)$ & 2.4776 & 2.5370 & 2.5733 & 0.074334 \\
\hline Milk Fat (\%) & $2.3244^{\mathrm{ab}}$ & $2.6921^{\mathrm{a}}$ & $2.0300^{\mathrm{b}}$ & 0.164709 \\
\hline Milk Lactose (\%) & 4.4315 & 4.5932 & 4.5693 & 0.079684 \\
\hline
\end{tabular}

${ }^{1}$ LD: Low Degradable diet; ${ }^{2} \mathrm{MD}$ : Medium Degradable diet; ${ }^{3} \mathrm{HD}$ : High Degradable diet a,b,c Means in the same row with different superscripts differ statistically $(\mathrm{P}<0.05)$

\section{References}

Brun-Bellut, J. \& Kelly, J.M., 1991. Can. J. Anim. Sci. 71, 1111.

Mishra, S. et al., 1996. Small Rum. Res. 20, 39. 